Original Research Paper

\title{
Pengaruh Pemberian Ekstrak Pinang (Areca Catechu L.) terhadap Kesintasan Telur Keong Mas (Pomacea Canaliculata Lamarck)
}

\author{
Angreni B. Liunokas ${ }^{1 *}$, Joice J. Bana², Djeffry Amalo ${ }^{3}$ \\ ${ }^{1}$ Program Studi Pendidikan Biologi, Sekolah Tinggi Keguruan dan Ilmu Pendidikan Soe, Kota Soe, Indonesia; \\ ${ }^{2,3}$ Jurusan Biologi, Fakultas Sains dan Teknik, Universitas Nusa Cendana, Kota Kupang, Indonesia;
}

\section{Riwayat artikel}

Received : 28 Juli 2019

Revised : 27 September 2019

Accepted : 19 November 2019

Published : 20 November 2019

*Corresponding Author:

Angreni B. Liunokas,

STKIP Soe, Kota Soe,

Indonesia;

Email:

liunokasrenni@gmail.com
Abstrak: Keong mas (Pomacea canaliculata Lamarck) merupakan hama potensial tanaman padi sawah yang berkembangbiak dengan sangat cepat sehingga sulit untuk menekan perkembangannya. Salah satu jenis tanaman yang dapat mengendalikan dan menekan populasi hama ini adalah pinang (Areca catechu $\mathrm{L}$ ). Penelitian tentang pengaruh pemberian ekstrak pinang terhadap kesintasan telur keong mas, telah dilaksanakan di Laboratorium Biologi Undana Kupang. Tujuan penelitian ini adalah untuk mengetahui: 1) pengaruh pemberian ekstrak biji pinang terhadap kesintasan telur keong mas, (2) nilai $\mathrm{LC}_{50}$ ekstrak biji pinang terhadap mortalitas telur keong mas, (3) nilai $\mathrm{LT}_{50}$ ekstrak biji pinang terhadap mortalitas telur keong mas. Dalam penelitian ini digunakan rancangan acak lengkap dengan enam perlakuan yang terdiri dari tiga ulangan. Data penelitian dianalisis dengan analisis ragam dan analisis probit untuk menghitung $\mathrm{LC}_{50}$ dan $\mathrm{LT}_{50}$. Hasil penelitian menunjukkan bahwa (1) pemberian ekstrak pinang efektif dalam menghambat dan mematikan telur keong mas serta memberikan pengaruh nyata terhadap kesintasan telur keong mas. (2) nilai $\mathrm{LC}_{50}$ ekstrak pinang adalah pada konsentrasi $18.899 \%$ dengan garis regresi $\mathrm{Y}=10.56+1.98 \mathrm{x}$ dan (3) nilai $\mathrm{LT}_{50}$ ekstrak pinang yaitu pada $72,980 \mathrm{jam}$. Pemanfaatan ekstrak pinang sangat direkomendasikan bagi petani padi sawah yang ingin membasmi hama keong mas.

Kata Kunci : A. catechu L., Telur P. canaliculata Lamarck, Kesintasan.

Abstract: Golden snail (Pomacea canaliculata Lamarck) has been potential pest for rice plant which quickly develops, therefore it is difficult to stop its growth. One kind of plant which is able to stop the growth is areca (areca catech $u$ L.). The influence of giving areca extract toward the development of golden snail's eggs has already been done by the Biology Laboratory of Undana Kupang. The aim of the study is to know: 1) the influence of areca extract toward the development of golden snail's eggs; 2) the $\mathrm{LC}_{50}$ value of areca extract on the mortality og golden snail's eggs; 3 ) the $\mathrm{LT}_{50}$ value of areca extract on the mortality of golden snail's eggs. Random technique was used with six sessions of treatment and three tests were implied. The analysis was done by classifying and also probility to count the value of $\mathrm{LC}_{50}$ and $\mathrm{LT}_{50}$. The result showed that (1) giving areca extract was effective to restrain and stop the development of golden snail's eggs and giving obvious influence toward the development of the eggs. (2) the value of $\mathrm{LC}_{50}$ areca extract was on the concentration of $18,899 \%$ with the regression was $Y=10.56+1.98 x$ and (3) the value of $\mathrm{LT}_{50}$ areca extract was on 72.980 hours. Therefore, making of areca extract is highly recommended for farmers especially in the rice field who want to prevent the grouth of golden snail.

Keywords : A. catechu L., P. canaliculata Lamarck egg, Survivorship. 


\section{Pendahuluan}

Kebutuhan manusia akan bahan pangan terus meningkat seiring berjalannya waktu, peningkatan jumlah penduduk tiap tahun menjadi suatu pemikiran terkait dengan masalah pangan. Produksi padi harus terus diupayakan mengingat jumlah penduduk Indonesia yang terus bertambah sementara beras untuk konsumsi merupakan makan pokok sebagian besar (90\%) penduduk Indonesia. Nusa Tenggara Timur (NTT) sebagai salah satu provinsi di Indonesia merupakan daerah potensial yang sebagian besar hidup penduduknya masih bergantung pada sektor pertanian terutama pada pertanian tanaman pangan seperti padi. Total luas lahan di provinsi NTT adalah 215.796.10 ha (BPS, 2012). Suparyono (1997) mengungkapkan bahwa usaha untuk meningkatkan produksi tanaman padi sawah menghadapi banyak hambatan, salah satunya adalah gangguan yang disebabkan oleh hama keong mas (Pomacea canaliculata Lamarck). Badan Pangan Dunia (FHO), memperkirakan jumlah kerusakan yang disebabkan oleh hama ini berkisar 10 $40 \%$.

Keong mas adalah herbivora golongan moluska yang sangat berbahaya karena menyerang padi pada umur muda sehingga pembentukan rumpun terhambat, menyerang daun sehingga daun menjadi berlubang dan terdapat jalur-jalur bekas makan yang menyebabkan gugurnya daun (Sulistyanto, 2006). Keong mas ini bersifat herbivor polifag (pemakan segala jenis tanaman), serta sangat rakus dan cepat dalam berkembang biak karena bersifat hermaprodit, seekor induk berumur 6 bulan mampu bertelur 1000 butir sekali bertelur. Populasi 8 ekor/m² menurunkan jumlah rumpun padi sampai 92\% (Soenaryo, et al., 1989).

Berdasarkan data Dinas Pertanian dan Perkebunan Provinsi NTT luas pertanaman padi sawah di NTT yang mendapat serangan organisme penggangu tanaman secara umum sebesar 15.351,5 ha dan keong mas menyerang tanaman padi seluas 8 ha. Hama tanaman dari golongan moluska seringkali menjadi hama potensial, karena umumnya berkembangbiak dengan cepat sehingga sulit untuk menekan perkembangannya (Kardinan dan Iskandar, 1997).

Cara pengendalian terhadap hama padi ini telah diterapkan, baik berupa tindakan mekanis dan pestisida. Pemakaian agen pestisida yang bersifat toksik bisa saja mengurangi jumlah populasi dalam waktu sesaat. Kebanyakan petani memilih untuk menggunakan pestisida kimia. Beberapa moluskisida yang terdaftar pada atoritas pestisida sampai 31 Maret 2009 antara lain Metabeit 6\% Pellets, Meta F1, Bayluscide 250 EC, Ciba Meta Bait, Moluxide 250 EC dan lain-lain. Hampir keseluruhan jenis moluskisida memiliki tingkat toksisitas yang agak berbahaya dan tidak menimbulkan bahaya akut dalam keadaan normal (Sebastian, 2010). Efek samping lain penggunaan pestisida kimiawi yaitu terjadi pencemaran lingkungan oleh residu kimiawi. Pestisida sering gagal menekan populasi hama ini. Hal ini diduga karena hama menjadi resisten terhadap pestisida kimiawi yang digunakan, sehingga perlu adanya alternatif pestisida baru yang lebih efisien (Sebastian, 2010). Permasalahan tersebut menyebabkan petani mulai mengeksplorasi bahanbahan alami yang dapat digunakan untuk pengendalian hama keong mas ini (Prijono, 2000).

Terdapat beberapa jenis tanaman yang dapat digunakan sebagai pestisida untuk mengendalikan keong mas, Lobo et al. (1991) dan Nizmah (1999) menemukan tanaman biduri (Calotropis gigantea) untuk mengendalikan keong mas, Kardinan (1997) mendapatkan tanaman tuba (Derris elliptica) yang efektif untuk pengendalian keong mas. Tanaman tuba dilaporkan lebih efektif untuk mengendalikan keong mas dibandingkan dengan tanaman biduri (Nguyen Huu, 2002) serta serbuk buah mengkudu (Morinda citrifolia) dilaporkan dapat menekan populasi pertumbuhan keong mas (Gassa, 2011).

Salah satu tanaman berpotensi untuk mengendalikan dan menekan populasi keong mas yaitu biji pinang (Areca catechu L.). Biji pinang dilaporkan mengandung zat arecoline tergolong alkaloid yang serupa dengan nikotin dapat merangsang otak (Gassa, 2011). Arecoline merupakan sebuah ester metaltetrahidrometil-nikotinat yang berwujud minyak basa keras, bersifat toksik dan menyebabkan kelumpuhan serta terhentinya pernafasan (Jaiswal et al, 2011). Zat tersebut digunakan dalam bentuk erecolinnum hydrobromicum dengan rumus kimia $\mathrm{C}_{8} \mathrm{H}_{13} \mathrm{NO}_{13}$. Pinang merupakan tanaman tradisional sehingga keberadaanya cukup banyak di NTT, tanaman ini di tanam untuk dimanfaatkan bijinya. Pemanfaatannya hanya sebatas bahan upacara adat sebagai lambang hubungan sosial budaya, digunakan bersama dengan buah sirih, dan kapur untuk menguatkan gigi, serbuk biji pinang juga dimanfaatkan untuk mengobati cacingan, terutama cacing pita dan sebagian besar hanya digunakan sebagai tanaman pekarangan atau pohon hias. Sedangkan pemanfaatan biji pinang untuk mengatasi hama keong mas belum dilakukan, sehingga peneliti melakukan penelitian tentang pengaruh pemberian ekstrak pinang terhadap kesintasan telur keong mas. Adapun tujuan dari penelitian ini adalah untuk mengetahui: (1) pengaruh pemberian ekstrak biji pinang terhadap kesintasan telur keong mas, (2) nilai $\mathrm{LC}_{50}$ ekstrak biji pinang terhadap mortalitas telur keong mas, (3) nilai LT $_{50}$ ekstrak biji pinang terhadap mortalitas telur keong mas. 


\section{Bahan dan Metode}

\section{Waktu pelaksanaan, alat dan bahan}

Penelitian ini telah dilaksanakan pada bulan Januari sampai Agustus 2012 di Laboratorium Biologi Universitas Nusa Cendana Kupang. Penelitian dilakukan dengan mengambil keong mas dari sawah desa Kaniti Kecamatan Kupang Tengah dan dipelihara hingga menghasilkan telur.

Bahan-bahan yang digunakan dalam penelitian ini adalah buah pinang segar yang diambil dari kebun masyarakat, telur keong mas dari keong mas betina yang dikumpulkan dari areal persawahan Desa Kaniti, etanol dan aquades. Selanjutnya alat-alat yang digunakan adalah stoples, wadah plastik, cawan petri, gelas ukur, labu ukur $25 \mathrm{ml}$ dan gelas ukur $5 \mathrm{ml}$, stopwatch, batang pengaduk, blender, alat penyaring halus, timbangan analitik, aluminium foil, beaker glass ukuran $250 \mathrm{ml}$ dan $500 \mathrm{ml}$, pipet ukur, rotary evaporator, lup dan kamera, kaen kasa, kaen belacu, plastik mika, karet gelang, alat tulis menulis dan kertas label.

\section{Penyediaan Telur Uji}

Penyediaan telur uji keong mas (Pomacea canaliculata Lamarck) dimulai dengan pengambilan keong mas yang sudah dewasa dari areal persawahan lalu ditempatkan pada kolam buatan (baskom) yang berisikan air. Setiap pagi dilakukan pemberian pakan dari daun papaya, kangkung dan daun talas. Sampai keong menghasilkan telur dan kemudian telur-telur tersebut dipidahkan ke dalam cawan petri yang dialasi kapas.

\section{Penyediaan Ekstrak Biji Pinang (Areca catechu L.)}

Buah pinang yang digunakan adalah buah pinang yang masih segar dan berwarna hijau tidak terlalu tua juga tidak terlalu muda yang diambil langsung dari pohon. Buah pinang yang terkumpul kemudian diibelah lalu dikeluarkan daging buahnya dicuci bersih denfan air untuk menghilangkan kotoran yang menempel, kemudia dikering anginkanpada suhu ruangan selama 48 jam, selanjutnya dimasukkan ke dalam oven dengan suhu $45^{\circ} \mathrm{C}$ selama 24 jam untuk menghilangkan kadar air dalam biji pinang, lalu dihaluskan dengan cara di blender untuk mendapatkan serbuk (simplisia) biji pinang.

\section{Pembuatan Ekstrak}

Ekstrak biji pinang dibuat dengan metode maserasi. Dengan menggunakan pelarut etanol. Biji pinang yang sudah di blender dan menjadi simplisia ditimbang sebanyak $300 \mathrm{~g}$ direndam dengan pelarut sebanyak $600 \mathrm{ml}$ dan dimaserasi selama 48 jam pada suhu kamar agar senyawa kimia yang dikandung dapat terurau dengan baik. Hasil rendaman disaring untuk memisahkan filtrate dan residunya yang kemudian residu dipekatkan dengan rotary evaporator dengan kisaran suhu $60-65^{\circ} \mathrm{C}$ untuk memisahkan dari pelarut etanol sehingga didapat ekstrak kasar biji pinang (Lapuimakuni, 2011).

\section{Uji Pendahuluan}

Uji pendahuluan ini dilakukan dengan tujuan untuk mendapatkan konsentrasi efektif dalam mematikan telur keong mas atau siput murbei dan juga jumlah telur keong mas yang digunakan pada uji inti. Konsentrasi yang dipakai yaitu 10\%, 20\%, 30\%, 40\%, 50\% dan kontol, masing-masing perlakuan terdiri dari 3 ulangan, dalam setiap ulangan terdiri dari 40 butir telur keong mas sehingga total telur keong mas yang digunakan adalan 720 butir (Setiya, 2007).

\section{Uji Inti}

Pelaksanaan uji inti menggunakan cawan petri yang dialasi kapas sebanyak 3,2 gr. Konsentrasi yang digunakan dalam pelaksanaan uji inti ini berdasarkan uji pendahuluan yaitu dengan konsentrasi sebagai berikut:

a) $\mathrm{P}_{0}$ : kontrol (0\%), hanya menggunakan aquades tanpa ekstrak biji pinang;

b) $\mathrm{P}_{1}$ : ekstrak biji pinang 10\% (1 ml ekstrak +9 ml aquades);

c) $\mathrm{P}_{2}$ : ekstrak biji pinang $20 \%(2 \mathrm{ml}$ ekstrak +8 ml aquades);

d) $\mathrm{P}_{3}$ : ekstrak biji pinang $30 \%(3 \mathrm{ml}$ ekstrak +7 ml aquades);

e) $\mathrm{P}_{4}$ : ekstrak biji pinang 40\% (4 ml ekstrak +6 ml aquades);

f) $\mathrm{P}_{5}$ : ekstrak biji pinang 50\% (5 $\mathrm{ml} \mathrm{ekstrak}+5$ $\mathrm{ml}$ aquades).

\section{Pengamatan}

Pengamatan dilakukan setiap hari terhadap mortalitas telur keong mas dengan menghitung jumlah telur yang tidak dapat menetas dalam jangka waktu 7-14 hari.

\section{Analisis Data}

Rancangan penelitian yang digunakan dalam penelitian ini adalah Rancangan Acak Lengkap dengan 6 perlakuan, setiap perlakuan terdiri dari 3 ulangan, masingmasing menggunakan 40 butir telur keong mas, sehingga dalam setiap perlakuan menggunakan 120 butir dan total telur keong mas yang digunakan adalah 720 butir. Konsentrasi ekstrak yang digunakan berdasarkan uji pendahuluan yaitu: $\mathrm{P}_{0}=$ kontrol $(0 \%)$, hanya menggunakan aquades tanpa ekstrak, $\mathrm{P}_{1}=$ ekstrak biji pinang 10\% ( $1 \mathrm{ml}$ ekstrak $+9 \mathrm{ml}$ aquades $), \mathrm{P}_{2}=$ ekstrak biji pinang $20 \%$ ( $2 \mathrm{ml}$ ekstrak $+8 \mathrm{ml}$ aquades $), \mathrm{P}_{3}=$ 
ekstrak biji pinang $30 \%$ (3 ml ekstrak $+7 \mathrm{ml}$ aquades), $\mathrm{P}_{4}$ $=$ ekstrak biji pinang $40 \%$ ( $4 \mathrm{ml}$ ekstrak $+6 \mathrm{ml}$ aquades $)$, $\mathrm{P}_{5}=$ ekstrak biji pinang 50\% (5 ml ekstrak $+5 \mathrm{ml}$ aquades).

Variabel yang diukur dalam penelitian ini adalah persentasi mortalitas telur keong mas dihitung menggunakan rumus $M=\frac{a}{a+b} \times 100 \%$ dan nilai $\mathrm{LC}_{50}$ serta $\mathrm{LT}_{50}$ yang menyebabkan mortalitas terefektif dari ekstrak biji pinang dalam jangka waktu 7-14 hari. Data kuantitatif hasil perlakuan di analisis dengan analisis sidik ragam yang menunjukkan perbedaam dilanjutkan dengan uji Duncan Multiple Range Test (Gaspersz, 1995) dan untuk besarnya nilai $\mathrm{LC}_{50}$ serta $\mathrm{LT}_{50}$ digunakan analisis probit program SPSS versi 11.0 for windows.

\section{Hasil dan Pembahasan}

\section{Mortalitas Telur Keong Mas}

Hasil uji pendahuluan pemberian ekstrak biji pinang terhadap kesintasan telur keong mas dengan menggunakan konsentrasi yang tertinggi dan konsentrasi terendah yaitu $10 \%$ dan $50 \%$ menunjukkan hasil pada $\mathrm{P}_{1}$ sebesar $38.33 \%$ dengan konsentrasi $10 \%$ dan $\mathrm{P}_{5}$ sebesar $100 \%$ dengan konsentrasi 50\%, maka dapat dikatakan bahwa ekstrak biji pinang bersifat toksik dimana dengan rentang konsentrasi tersebut dapat menyebabkan mortalitas pada telur keong mas. Berdasarkan uji pendahuluan ini maka dilanjutkan dengan uji inti dengan rentan konsentrasi sesuai dengan uji pendahuluan yakni 10\%, 20\%, 30\%, 40\%, dan 50\%. Hasil uji pendahuluan dapat dilihat pada tabel 1 .

Tabel 1. Mortalitas Telur Pomacea canaliculata Lamarck Pada Uji Pendahulan

\begin{tabular}{|c|c|c|c|c|}
\hline \multirow{2}{*}{ Perlakuan } & \multicolumn{3}{|c|}{ Ulangan } & \multirow{2}{*}{$\begin{array}{c}\text { Rerata } \\
(\%)\end{array}$} \\
\cline { 2 - 4 } & $\mathbf{1}$ & $\mathbf{2}$ & $\mathbf{3}$ & \\
\hline \hline $\mathbf{P}_{\mathbf{1}}(\mathbf{1 0 \%})$ & 25 & 50 & 40 & 38.33 \\
\hline $\mathbf{P 5}_{\mathbf{5}}(\mathbf{5 0 \%})$ & 100 & 100 & 100 & 100 \\
\hline
\end{tabular}

Hasil pengamatan pada uji inti terlihat bahwa ekstrak biji pinang menimbulkan mortalitas telur keong mas. Gejala mortalitas telur keong mas terhadap ekstrak biji pinang memperlihatkan respon fisik pada 24 Jam Setelah Perlakuan (JSP) berupa perubahan warna kulit telur keong mas dari warna merah muda terang menjadi merah muda keputih-putihan atau pucat, tidak terdapat lagi zat kapur pada kulit yang merupakan pelindung bagi telur terhadap gangguan/predator, lama kelamaan telur mulai menyusut (kekurangan cairan) dikarenakan adanya senyawa metabolit sekunder bersifat toksik. Pitijo
(1996) menyatakan bahwa kepekaan suatu organisme terhadap gangguan dapat disebabkan oleh sistem penghalang adanya gangguan yang terdapat dalam organisme tersebut, misalnya pada telur Pomacea canaliculata ini yang dilengkapi dengan zat kapur pada kulit telur sehingga dapat mengurangi atau menyingkirkan gangguan dari telur, sehingga pada perlakuan uji inti terlihat bahwa terdapat telur yang masih mampu untuk menghalangi senyawa metabolit sekunder dari ekstrak pinang. Hasil pengamatan pemberian ekstrak biji pinang terhadap kesintasan telur keong mas dapat dilihat pada tabel 2.

Tabel 2. Mortalitas Telur Pomacea canaliculata Lamarck Akibat Pemberian Ekstrak Biji Pinang

\begin{tabular}{|c|c|c|c|c|}
\hline \multirow{2}{*}{ Perlakuan } & \multicolumn{3}{|c|}{ Ulangan } & \multirow{2}{*}{ Rerata } \\
\cline { 2 - 4 } & $\mathbf{1}$ & $\mathbf{2}$ & $\mathbf{3}$ & \\
\hline \hline $\mathrm{P}_{0}$ (kontrol) & 0 & 0 & 0 & $0^{\mathrm{a}}$ \\
\hline $\mathrm{P}_{1}(10 \%)$ & 37,5 & 40 & 40 & $39,17^{\mathrm{b}}$ \\
\hline $\mathrm{P}_{2}(20 \%)$ & 52,5 & 47,5 & 50 & $50^{\mathrm{c}}$ \\
\hline $\mathrm{P}_{3}(30 \%)$ & 77,5 & 77,5 & 75 & $76,67^{\mathrm{d}}$ \\
\hline $\mathrm{P}_{4}(40 \%)$ & 95 & 97,5 & 92,5 & $95^{\mathrm{e}}$ \\
\hline $\mathrm{P}_{5}(50 \%)$ & 100 & 100 & 100 & $100^{\mathrm{e}}$ \\
\hline
\end{tabular}

Ket: Superskrip yang sama menunjukkan perlakuan berbeda tidak nyata pada uji DMRT $(p=0,05)$.

Hasil analisis data menunjukkan bahwa adanya pengaruh nyata perlakuan konsentrasi ekstrak biji $A$. catechu terhadap kesintasan telur $P$. canaliculata Lamarck. Hasil uji statistik menggunakan analisis ragam pada nilai rataan presentase kesintasan telur keong mas akibat perlakuan menunjukkan adanya pengaruh nyata $(P=0,05)$, uji Duncan diperoleh bahwa perlakuan $\mathrm{P} 0$ berpengaruh nyata dengan perlakuan $\mathrm{P}_{1}$, $\mathrm{P}_{2}, \mathrm{P}_{3}, \mathrm{P}_{4}, \mathrm{P}_{5}$. Hal ini disebabkan karena telur keong mas pada perlakuan $\mathrm{P} 0$ hanya diberikan aquades tanpa perlakuan ekstrak biji pinang sehingga dapat menunjukkan perkembangan normal yang ditandai dengan menetasnya telur-telur keong mas. Perlakuan P1 berbeda nyata dengan P0, P2, P3, P4, dan P5 sedangkan P4 dan P5 berbeda tidak nyata. Hal ini membuktikan bahwa ekstrak biji pinang berpengaruh pada mortalitas telur keong mas seiring dengan bertambahnya konsentrasi ekstrak Areca catechu.

Adanya pengaruh nyata perlakuan berbagai konsentrasi disebabkan karena pada setiap konsentrasi ekstrak biji memiliki kandungan arekoline dari golongan alkaloid, golongan tannin dan saponin yang 
berbeda pua, sehingga daya bunuh pada telur yang berbeda tergantung banyak sedkitnya konsentrasi ekstrak biji A. catechu. Jaiswal et al. (2011) menjelaskan penggunaan serbuk biji pinang sebaiknya tidak lebih dari 4 gram per liter pelarut, jika digunakan melebihi dosis dalam jangka waktu panjang akan mengakibatkan penurunan daya hidup sel serta penurunan kecepatan sintesis DNA dan protein.

Selain arekolin terdapat senyawa bioaktif lain yaitu saponin yang bersifat toksik terhadap sel karena saponin memiliki sifat larut air. Ini didukung oleh Subiyakto (2000), yang menyatakan bahan aktif yang memiliki sifat larut tinggi dalam air akan menembus lapisan fosfolipid membran sel sehingga lebih cepat mengganggu fungis fisologis, pada akhirnya sel akan mengalami kematian, dan juga menghambat proses penetasan telur. Prijono (2000) menjelaskan bahwa semakin pekat konsentrasi larutan berarti semakin banyak kandungan bahan aktif yang dapat menggangu proses metabolisme. Kematian telur terjadi karena peristiwa plasmolisis yaitu keluarnya isi cairan sel karena diberikan larutan hipertonik, dimana isi sel memiliki potensial air yang tinggi sehingga air dalam sel keluar (Woelaningsih, 1984). Isi sel telur akan mengecil sehingga membran sel telur terpisah dari dinding sel dan akan tampak seperti ruang kosong dalam telur $P$. canaliculata Lamarck dan lama kelamaan akan menyebabkan robeknya dinding sel telur. Hal ini didukung oleh Kardinan (2002) yang menyatakan bahwa untuk mengendalikan hama diperlukan suatu komponen yang dapat menggangu keseimbangan proses fisiologi hama karena proses ini merupakan proses yang rentan.

Pemberian ekstrak biji A. catechu mengakibatkan telur tidak dapat menetas dikarenakan arekolin yang menghambat proses perkembangan di dalam telur sehingga tidak mampu lagi melangsungkan proses fisiologisnya, mengalami penurunan daya hidup serta penurunan kecepatan sintesis DNA, protein dan kerusakan enzim glutational yang berfungsi melindungi sel dari efek merugikan (Aradilla, 2009).

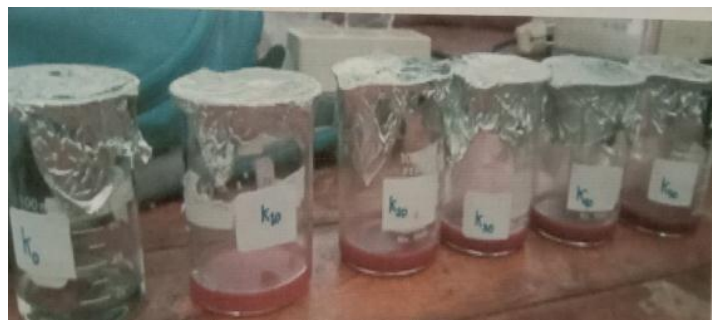

Gambar 1. Ekstrak biji Areca catechu L. dengan beberapa pengenceran.

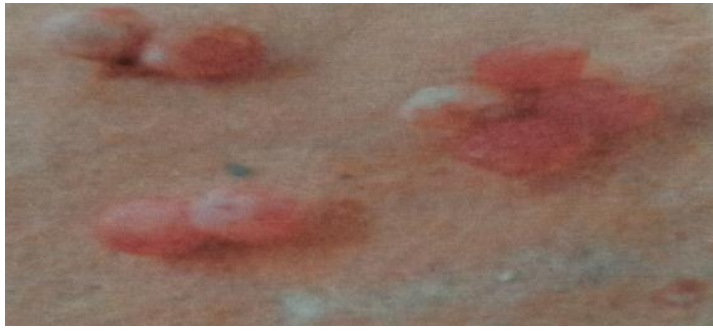

Gambar 2. Telur Pomacea canaliculata Lamarck saat pemberian ekstrak biji pinang.

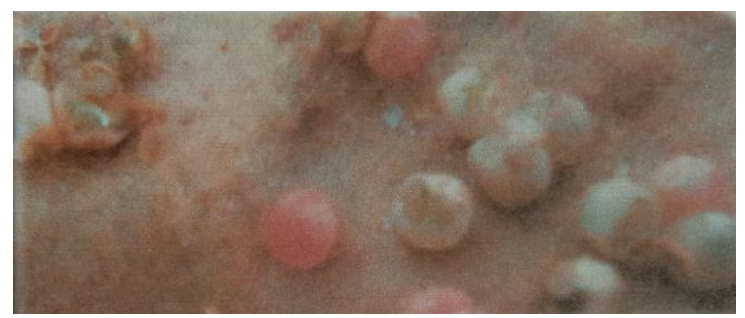

Gambar 3. Telur Pomacea canaliculata Lamarck yang mengalami plasmolisis dan robeknya cangkang.

Konsentrasi ekstrak biji A. catechu memberikan pengaruh pada kesintasan telur $P$. canaliculata. Rata-rata presentase mortalitas tertinggi diperoleh pada perlakuan P5 (100\%) sedangkan presentase mortalitas terendah oleh perlakuan P0 (0\%) terlihat pada Grafik 1. Hal ini diduga apabila ada penambahan konsentrasi maka kematian juga semakin bertambah dengan demikian semakin tinggi konsentrasi ekstrak biji $A$. catechu semakin tingi pula kadar arecoline dan senyawa bioaktif lain yang larut didalamnya.

Grafik 1. Pengaruh Pemberian Ekstrak Biji Pinang (Areca catechu L.) Terhadap Mortalitas Telur Keong Mas (Pomacea canaliculata Lamarck).

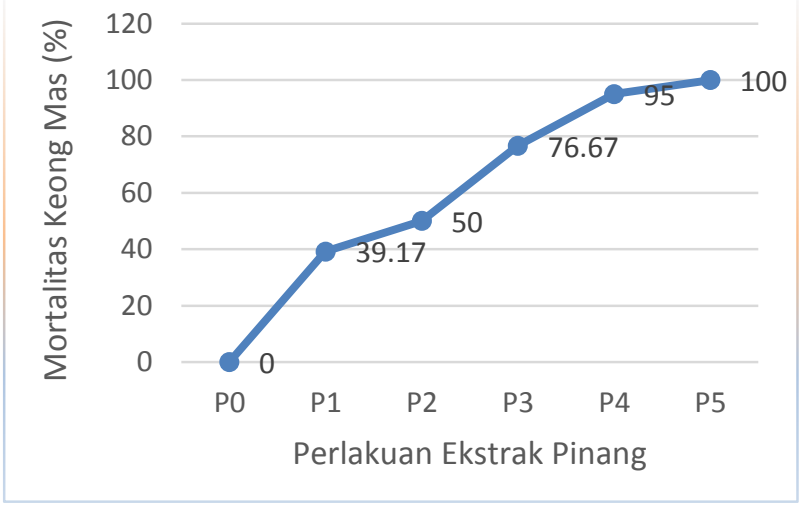

Dari perlakuan ternyata ekstrak biji A. catechu dapat menghambat penetasan telur hingga $100 \%$ atau telur tidak menetas semuanya pada perlakuan dengan 
konsentrasi 50\%, sehingga penggunaan ekstrak ini bereaksi relatif cepat dan bersifat menghambat penetasan secara cepat. Penetasan telur pada Pomacea canaliculata dengan berbagai konsentrasi menunjukkan perbedaan yang nyata dengan kontrol, dimana kontrol terlihat mengalami penetasan, hal ini dikarenakan pada perlakuan kontrol tidak dipengaruhi oleh zat toksin apapun sehingga aktivitas metabolisme dalam telur tidak terganggu.

Pemberian ekstrak biji A. catechu mengakibatkan telur tidak menetas dan menunjukkan ciri sebagai berikut: 1) cangkang telur tetap utuh, isi atau cairan sel telur tetap utuh tetapi telur tetap tidak dapat menetas dikarenakan arecolin yang menghambat proses perkembangan didalam telur sehingga telur tidak mampu lagi untuk melangsungkan proses fisiologisnya, mengalami penurunan daya hidup, serta kecepatan sintesis DNA, protein dan kerusakan enzim glutational yang berfungsi melindungi sel dari efek merugikan (Andria, 2011). 2) Cangkang telur robek dan isi cairan sel telur keluar, hal ini disebabkan karena terjadinya peristiwa plasmolisis, dimana lepasnya protoplasma dari dinding sel yang mengakibatkan keluarnya sebagian besar air dari dalam vakuola sehingga sel tidak dapat lagi mencegah kehilangan air. Isi sel mulai mengecil lama kelamaan menyebabkan robeknya dinding sel telur dan akhirnya cangkang dari telur keong mas ini juga robek namun keong mas muda tidak terlihat.

Berdasarkan pengamatan setelah aplikasi moluskisida nabati ekstrak biji pinang yang mengandung arecoline ini dapat dikatakan sangat efektif karena mampu mengakibatkan kematian dengan tingkat $100 \%$ telur tidak menetas semuanya pada konsentrasi $50 \%$, dengan reaksi relatif cepat dalam menghambat penetasan pada berbagai konsentrasi dengan menunjukkan perbedaan nyata dengan kontrol yang mengalami penetasan dikarenakan tidak dipengaruhi oeh zat racun apapun sehingga aktivitas metabolisme dalam telur pomacea canaliculata tidak terganggu.

\section{Lethal Concentration 50 (LC50)}

Lethal Concentration $50 \quad\left(\mathrm{LC}_{50}\right)$ merupakan konsentrasi ekstrak yang menyebabkan terjadinya kematian pada $50 \%$ hewan percobaan. Besarnya nilai $\mathrm{LC}_{50}$ diketahui dengan melakukan analisis probit menggunakan program SPSS 11.0 for windows dan hasilnya dapat dilihat pada tabel 2 .
Tabel 2. Hasil Analisis Probit Lethal Concentration 50 $\left(\mathrm{LC}_{50}\right)$ Ekstrak Biji Pinang (Areca catechu L.)

\begin{tabular}{|c|c|c|c|}
\hline \multirow{2}{*}{\begin{tabular}{c}
\multirow{2}{*}{$\begin{array}{c}\text { LC }_{50} \\
(\%)\end{array}$} \\
Kemungkinan
\end{tabular}} & \multicolumn{2}{|c|}{ Vidua Limits } \\
\cline { 3 - 4 } & & $\begin{array}{c}\text { Batas } \\
\text { Bawah }\end{array}$ & $\begin{array}{c}\text { Batas } \\
\text { Atas }\end{array}$ \\
\cline { 2 - 4 } & $\mathbf{1 8 , 8 9 9}$ & 17,332 & 20,426 \\
\hline
\end{tabular}

Hasil analisis probit didapatkan nilai $\mathrm{LC}_{50}$ $18,899 \%$ dengan batas bawah 17,332 dan batas atas 20,426 yang artinya pada konsentrasi $18,899 \%$ diduga telur keong mas mengalami kematian $50 \%$ dari jumlah seluruhnya dan juga pada konsentrasi $17,332 \%$ dapat mencapai $50 \%$ mortalitas keong mas, tetapi bila dibawah angka tersebut tidak termasuk $\mathrm{LC}_{50}$ demikian pula halnya dengan batas atas $20,426 \%$ dan apabila di atas dari nilai tersebut maka tidak lagi termasuk $\mathrm{LC}_{50}$ ekstrak biji pinang.

Aktivitas suatu moluskisida dilihat dari nilai toksisitasnya, dimana semakin kecil nilai LC $_{50}$ suatu bahan, semakin tinggi bioaktivitasnya (Pasaribu, 2009). Nilai LC $_{50}$ ekstrak $A$. catechu menunjukkan bahwa pinang memiliki toksisitas yang tinggi atau memiliki toksisitas akut dengan nilai $18,899 \%$. Berdasarkan nilai $\mathrm{LC}_{50}$ yang diperoleh dari analisis probit maka dilanjutkan dengan analisis regresi dengan persamaan $\mathrm{Y}=\mathrm{a}+\mathrm{bx}$, untuk melihat adanya hubungan antara konsentrasi ekstrak biji $A$. catechu dengan mortalitas telur $P$. canaliculata.

Hasil analisis regresi dengan $\mathrm{Y}=10.56+1,98 \mathrm{x}$ menunjukkan adanya korelasi positif antara konsentrasi dan persentase mortalitas telur $P$. canaliculata Lamarck, dimana terlihat bahwa setiap kenaikan $1 \mathrm{ml}$ konsentrasi ekstrak $A$. catechu $\mathrm{L}$ dapat menyebabkan kematian 1.98 butir atau 2 butir telur $P$. canaliculata Lamarck dan terlihat bahwa semakin tinggi konsentrasi ekstrak semakin tinggi pula prosentase telur $P$. canaliculata Lamarck yang tidak menetas atau mati.

\section{Lethal Time 50 (LT50)}

$\mathrm{LT}_{50}$ adalah waktu yang dihitung dengan suatu konsentrasi kimiawi yang mengakibatkan kematian $50 \%$ populasi hewan percobaan. $\mathrm{LT}_{50}$ digunakan untuk menentukan apakah ekstrak biji pinang efektif untuk digunakan pada waktu tertentu. Berdasarkan analisis probit didapatkan nilai $\mathrm{LT}_{50}$ pada masing masing konsentrasi perlakuan dan besarnya nilai $\mathrm{LT}_{50}$ ekstrak biji A. catechu dapat dilihat pada tabel 3 . 
Tabel 3. Hasil Analisis Probit Lethal Time 50 ( $\left.\mathrm{LC}_{50}\right)$ Ekstrak Biji Pinang (Areca catechu L.)

\begin{tabular}{|c|c|c|c|}
\hline \multirow{2}{*}{\begin{tabular}{c}
\multirow{2}{*}{$\begin{array}{c}\text { LC } \\
(\%)\end{array}$} \\
\%0
\end{tabular}} & \multirow{2}{*}{ Kemungkinan } & \multicolumn{2}{|c|}{ Vidua Limits } \\
\cline { 3 - 4 } & & $\begin{array}{c}\text { Batas } \\
\text { Bawah }\end{array}$ & $\begin{array}{c}\text { Batas } \\
\text { Atas }\end{array}$ \\
\cline { 2 - 4 } & $\mathbf{7 2 , 9 8 0}$ & 69,301 & 76,595 \\
\hline
\end{tabular}

Hasil analisis probit didapatkan nilai $\mathrm{LT}_{50}$ yaitu 72.98 jam dengan batas bawah 69,301 jam dan batas atas 76,595 jam dimana selang waktu tersebut sudah dapat mematikan $50 \%$ telur $P$. canaliculata Lamarck artinya pada selang waktu 72,980 jam diduga telurtelur keong mas ini mencapai $50 \%$ mortalitas telur keong mas, apabila kurang dari nilai tersebut maka tidak tergolong $\mathrm{LT}_{50}$ demikian pula dengan batas atas. Berdasarkan hasil ini dikatakan bahwa ekstrak $A$. catechu berpengaruh terhadap waktu penetasan karena mampu memperlambat waktu penetasan telur bahkan sampai tidak menetas atau mati dalam waktu 72.98 jam.

\section{Daftar Pustaka}

Aradilla, A. S. (2009). Uji Efektifitas Larvasida Ekstrak Etanol Daun Mimba (Azadirachta indica) Terhadap Larva Aedes aegypti. Fakultas Kedokteran. Universitas Diponegoro. Semarang.

Andria Agusta. (2001). Uji Fitokimia Biji Pinang. Laboratorium Fitokimia. Puslitbang BiologiLIPI Bogor. Bogor

Badan Pusat Statistik Provinsi NTT. (2012). Luas Lahan Sawah Menurut Kabupaten/Kota di Provinsi Nusa Tenggara Timur, 2008-2012. Provinsi Nusa Tenggara Timur Dalam Angka

Gaspersz, V. (1995). Teknik Analisis Dalam Penelitian Percobaan. Tarsito Bandung. Bandung.

Gassa, A., Sulaeha dan Yuyun S. (2008). Uji Keefektifan Ekstrak Buah Pinang (Areca catechu L.) Terhadap Tingkat Mortalitas Jentik Nyamuk Culex sp. (Diptera: Culicidae). Jurusan Hama dan Penyakit Tumbuhan. Fakultas Pertanian Universitas Hasanuddin. Makasar

Handayani, D. (2013). Uji Efektivitas Pengendalian Keong Mas (Pomacea canaliculata Lamarck) Pada Padi Sawah dengan Menggunakan Rendaman Air Kapur Sirih $\left(\mathrm{CaCO}_{3}\right)$ dan Ekstrak Daund Ubi Karet (Manihot glaziovii M.A). Jurnal

\section{Kesimpulan}

Berdasarkan hasil analisis data dan pembahasan pada penelitian ini maka dapat disimpulkan bahwa: (1) Pemberian ekstrak biji A. catechu efektif dalam menghambat dan mematikan telur $P$. canaliculata Lamarck, (2) serta memberikan pengaruh nyata terhadap kesintasan telur Pomacea canaliculata dimana semakin tinggi konsentrasi ekstrak biji A. catechu yang diberikan maka semakin besar pengaruhnya. (3) Nilai LC $\mathrm{C}_{50}$ ekstrak biji Areca catechu berdasarkan hasil analisis probit adalah sebesar 18,899\% dengan abtas bawah $17,332 \%$ dan batas atas 20,426\%. (4) Nilai $\mathrm{LT}_{50}$ ekstrak biji Areca catechu berdasarkan analisis probit adalah sebesar 72.98 Jam dengan abtas bawah 69,301 jam dan batas atas 76,595 jam.

\section{Ucapan Terima Kasih}

Penulis mengucapkan terima kasih kepada Jurusan Biologi Fakultas Sains dan Teknik Universitas Nusa Cendana Kupang atas bimbingan dan dukungan baik moril maupun materil.

EduBio Tropika. 1 (2): 61-120.

Harahap, S. (2017). Metode Pengendalian Hama Keong Mas (Pomacea canaliculata L.) dengan Pola Pengairan dan Beberapa Umpan Perangkap Terhadap Produksi Padi Sawah (Oryza sativa L.). Jurnal Agrohita. 1 (2): 64-69.

Harbone, J. B. (1996). Metode Fitokimia, Penuntun Cara Modern Menganalisis Tumbuhan. Terbitan Kedua. ITB Bandung. Bandung

Indraswari, A. (2008). Skripsi Optimasi Pembuatan Ekstrak Daun Dewandaru (Eugenia uniflora L.) Menggunakan Metode Maserasi Dengan Parameter Kadar Total Senyawa Fenolik dan Flavonoid. Fakultas Farmasi. Universitas Muhammadiyah Surakarta.

Jaiswal, P., Kumar, P., Singh, V. K. (2011). "Areca catechu L.: A Valuable Medicine Againt Different Health Problems". Research Journal of Medicinal Plant. 5 (2): 145-152.

Kardinan, A. (2002). Pestisida Nabati Ramuan dan Aplikasi. PT Penebar Swadaya, Jakarta.

Kardinan, A dan M. Iskandar. (1997). Pengaruh Beberapa Jenis Ekstrak Tanaman Sebagai Moluskisida Nabati Terhadap Keong Mas (Pomacea canaliculata Lamarck). Jurnal Perlindungan 
Tanaman Indonesia, Jurnal Hama Penyakit Tumbuhan. Fakultas Pertaniasn UGM Yogyakarta. 3 (2):82-90.

Lapuimakuni, S. (2011). Analisis Kandungan Antioksidan Ekstrak Kelopak Rosella (Hibiscus sabdariffa Linn) dengan Menggunakan Metode DPPH (1, 1- diphenyl-2-picrilhidrazyl). Jurusan Biologi Fakultas Sains dan Teknik Universitas Nusa Cendana Kupang. Kupang.

Lobo, $\mathrm{P}$ and Wada, T. (1991). Evaluation of the Star Flower (Calontropis gigantea) against the Golden Apple Snail (Pomacea canaliculata) in Low Land Transplanted Rice. Philipp J. Crop Sci. 16 (3): 103-107.

Manueke, J. (2016). Pengendalian Hama Keong Emas (Pomacea canaliculata Lamarck) Pada Tanaman Padi Sawah dengan Menggunakan Ekstrak Buah Bitung (Barringtonia asiatica L.). Jurnal LPPM Bidang Sains dan Teknologi. 3 (1):19-26.

Nguyen Huu and Ravindra C. Joshi. (2002). Golden apple situation and integrated management activities in sounth Vietnam. Proceeding of the Special Working Group on the Golden Apple Snail (Pomacea spp) at the Seventh International Congress on Medical and Applied Malacology $\left(7^{\text {th }}\right.$ ICMAM). Searca. Los Banos, Laguna, Philippines. October 2002. 55-56

Nizmah. (1999). Uji Toksisitas Ekstrak Tanaman Widuri (Calontropis gigantea) Terhadap Hama Keong Mas (Pomacea canaliculata). Seminar Nasional Biologi XV. Hal. 970-973

Prijono, D. (2000). Pengembangan dan Pemanfaatan Insektisida Alami. Pusat Kajian Pengendalian Hama Terpadu IPB. Bogor.

Setiya, T. (2007). Ekstrak Biji Mimba (Azadirachta indica A. Juss) Sebagai Solusi Alternatif Pengendalian Hama Telur Keong Mas (Pomacea canaliculata Lamarck) Pada Tanaman Padi. Karya Ilmiah pada FKIP-Biologi. Universitas Muhammadiyah Malang. Malang.

Siregar, A.Z., Tulus dan Kemala, S. L. (2017). Pemanfaatan Tanaman Atraktan Mengendalikan Hama Keong Mas Padi. Jurnal Agrosains dan Teknologi. 2 (2):121-134.

Soenaryo, E., P. Panuju dan M. Syam. (1989). Siput Murbei: Siput indah yang dapat menimbulkan malapetaka bagi pertanaman padi sawah. Warta Penelitian dan Pengembangan Pertanian, Deptan RI. XI (5): 1-4

Subiyakto. (2000). Pestisida Nabati: Pembuatan dan Pemanfaatannya. Kanisius. Jakarta.

Woelaningsih, Sri. (1984). Diktat Penuntun Praktikum Botani Dasar Sitologi. Lab. Anatomi Tumbuhan Fakultas Biologi UGM. Yogyakarta. 